\title{
Digital Storytelling for Twenty-First-Century Competencies with Math Literacy and Student Engagement in China and Finland
}

\author{
Hannele Niemi \\ University of Helsinki, Finland \\ Shuanghong Niu \\ University of Helsinki, Finland \\ Marianna Vivitsou \\ University of Helsinki, Finland \\ Baoping Li \\ Beijing Normal University, China
}

Submitted: 10.09.2018

Accepted: 09.10.2018

Published: 16.10 .2018

\begin{abstract}
The aim of this digital storytelling (DST) study was to investigate how students acquire twentyfirst-century competencies, here focusing on active knowledge creation and collaboration in math learning. The study also examined how engaged the students were in DST lessons and what teachers' perceptions of DST were as a learning method. DST was implemented in four Chinese and two Finnish classes with 10- and 11-year-old students. Data were collected quantitatively and qualitatively. The students assessed their learning experiences with structured questionnaires during and after the study. Students' behavior was also observed, and the teachers were interviewed. Quantitative data were analyzed using descriptive statistics and a linear regression analysis, and the qualitative data were analyzed using a content analysis. The study showed that the DST method guided students toward active collaborative learning; the students learned how to work in groups to produce new ideas, and they learned not only about math but also about how math relates to everyday life. The students were highly engaged throughout the study. Similarly, the teachers reported that the students displayed active knowledge creation and increased motivation and engagement. Results indicate that DST encourages students to apply new technology in their learning and supports students' development in math literacy and twenty-first-century competencies.
\end{abstract}

Keywords: Digital storytelling; Twenty-first-century competencies; Math literacy; Student engagement

\section{Introduction}

Across the globe, how to prepare students for the future is a major concern for educators (e.g., Binkley et al., 2012; Griffin, McGaw, \& Care, 2013). Despite large differences in national educational systems, cultures, and histories, all countries face major changes in learning and knowledge creation. Learners are expected to master inquiring skills, but they must also construct their own knowledge base using different information sources and technological tools. The Organization for Economic Cooperation and Development [OECD] (OECD, 2013) conducted an 
extensive research project called Innovative Learning Environments. The project has convincingly shown that information and communication technology (ICT) must become an essential component in current and future learning environments. In the present study, digital storytelling (DST) is implemented in schools using multimodal knowledge creation tools, such as digital mobile technology and tablets for video creation. DST was integrated with subject matter learning and also with future demands that are often described as twenty-first-century competencies (e.g., Lee \& Tan, 2018; OECD, 2013).

The current study investigates how students in China and Finland can acquire twenty-first-century competencies through digital storytelling and enhance their understanding of math in everyday life while becoming more engaged in learning. China-a country with a large population-and Finland-a country with a small population-are equally aware that students need new skills and competencies to cope with the ever-changing global world, and capability to use ICT in learning that prepares students for the future (e.g., CNNIC, 2017; Niemi \& Jia 2016; Säljö, 2010, 2012; Statistics Finland, 2016). However, both countries face similar opportunities and challenges. New technology and digital environments provide many new tools for teaching and learning (e.g., Domingo \& Gargante, 2016; Niemi, Kynäslahti, \& Vahtivuori-Hänninen, 2013; OECD; 2013; Penttilä et al., 2016; Säljö, 2012), but earlier studies have shown that in most countries, including China and Finland, schools need new pedagogical models and practices to integrate technology with the instruction of subject matters (Niemi \& Jia, 2016). In both countries, technology is seen as a tool, not an aim in and of itself, and new digital tools and materials should be pedagogically relevant. In the present study, the purpose is not to compare students' learning outcomes as such; the aim, instead, is discovering-from both contexts-how DST promotes students' learning and motivation. The aim of the study is to find how digital technology integrated with a subject matter and also with more generic transferable competencies can support students' learning and motivation.

Although the need for future competencies has been recognized globally, schools are not well prepared when it comes to using methods that lead to these competencies (e.g., Niemi et al., 2013; Saavedra \& Opfer, 2012; Schleicher, 2015). In the present study, Chinese and Finnish researchers collaborated with the aim of finding ways to address this gap in their respective countries' education systems. After presenting a literature review of DST as a pedagogical method, twenty-first-century competencies are reflected on and included in the current study. Thereafter, the concepts of math literacy and engagement are introduced, showing how these are related to the study. After presenting the research findings, there are reflections on what DST can provide for teaching and learning.

\section{Literature review}

\section{Digital Storytelling}

DST has become a widely investigated area across the globe, with studies found in the United States, Europe, and various Asian and Arabic countries. Jenkins, Purushotma, Clinton and Robison (2009) have described DST as a twenty-first-century learning mode. Most of the current literature on DST focuses on empowering students in their own lives or social contexts (Hull \& Katz, 2006; Hull, Zacher, \& Hibbert, 2009; Stewart \& Ivala, 2017). Increasingly, DST studies have had a greater focus on school subjects. DST can support students' understanding of both simple and complex subject matters, as well as improve their technical, presentation, and writing skills. Robin (2008) found that DST also cultivates students' higher-order thinking, such as problem 
solving and critical thinking. According to Yang and Wu (2012), DST participants performed well not only in terms of English achievement, but also in critical thinking and learning motivation. Hung, Hwang, and Huang (2012) applied a project-based DST approach to a science course at an elementary school and concluded that storytelling could effectively enhance students' motivation, problem-solving competencies, and learning achievement. Comparable results have been shown in higher education settings (Blas \& Paolini, 2013; Robin, 2008; Wang \& Zhan, 2010). DST has also been applied in teacher education (e.g., Starcic, Solomonides, \& Volk, 2016)

Earlier studies (Kearney, 2009; Yang \& Wu, 2012) have also shown that DST increases students' engagement by making them active learners. In different countries, the results of DST in school settings (e.g., Domingo \& Gargante, 2016; Niemi \& Multisilta, 2015; Starcic et al., 2016) have shown that DST increases content knowledge and collaboration, encouraging active participation and shared learning that boosts student engagement. DST has been shown to have a strong positive influence on motivation during the designing and filming of videos. DST has been examined in science and history and within the realm of numerous societal and ethical issues, such as poverty, homelessness, and animal testing. However, the present study applied DST to primary school math learning to see how twenty-first-century competencies, studentdriven math learning, and DST could be combined.

In many DST studies, the aim has been to promote learning through connective technologies and digital mobile devices to produce meaningful stories (McGee, 2015). In addition, when using DST, it can be implemented individually or collaboratively; in the current study, the method is implemented collaboratively. According to Niemi et al. (2014) and Niemi and Multisilta (2015), learning through DST is a socially and culturally related process that occurs when there are interactions among learners, material tools, psychological tools, and other people (Vygotsky, 1978). DST also builds on the constructivist learning model in which students play a central role in exploring and building knowledge in a digital learning environment as creators, producers, and discussants rather than as mere passive listeners. Many studies (e.g., Lambert, 2013; McGee, 2015; Multisilta \& Niemi, 2017; Niemi \& Multisilta 2015; Sadik, 2008; Shelby-Caffey, Úbéda, \& Jenkins, 2014; Sukovic, 2014; Woodhouse, 2008) have shown evidence that DST highlights participatory and constructive practices when creating the story.

In the present study, DST is applied to math learning, specifically how to calculate areas in geometry. The aim was to get the students to learn content knowledge, but also how to connect what they learned with real-life applications by using video technology, eventually teaching their peers through those videos.

\section{Twenty-first-Century Competencies and DST as an innovative learning environment}

Several definitions of twenty-first-century competencies can be found in the literature (e.g., Binkley et al., 2012; Griffin et al., 2013; Lee \& Tan, 2018). Lee and Tan (2018) reviewed various frameworks of definitions (2018) and concluded that all of these frameworks identify and describe the key competencies that are crucial to the knowledge economy and to the quality of citizenship required in the twenty-first century. Despite the varied emphases of these frameworks, they all mention certain common skills, such as creativity, innovation, critical thinking, problem solving, communication skills, collaboration, information and digital literacy, conflict resolution, and social and intercultural skills. Andreas Schleicher (2015, p. 3), division head and coordinator of the OECD Program for International Student Assessment and the OECD Indicators of Education Systems Program, asserted that education systems need to be 
transformed to incorporate the teaching of twenty-first-century competencies: "In the past, education was about teaching people something. Now, it is about making sure that individuals develop a reliable compass and the navigation skills to find their own way through an increasingly uncertain, volatile and ambiguous world." The OECD (2013) has developed a framework for innovative learning environments that promotes twenty-first-century competencies, citing the most essential learning principles, which are based on a meta-analysis of how to use learning research as a basis for future schools (Dumont, Istance, \& Benavides, 2010). The most important features of innovative learning environments are that they facilitate learners in understanding themselves as learners and encourage their engagement in learning. In addition, schools need to ensure that learning is social and collaborative. The importance here is having a horizontal connectedness across learning activities and subjects both in and out of school.

Learning occurs through dialogical interactions between people, substances, and artifacts (Cole \& Cigagas, 2010; Derry et al., 2010; Hakkarainen, Paavola, Kangas, \& Seitamaa-Hakkarainen, 2013; Pea, 2004; Säljö, 2012). In this context, learner-created videos are artifacts that challenge users to learn more, step outside their earlier proximal zones of learning, and enter a higher plane. Sociocultural theories can be attributed to Vygotsky's (1978) thinking. The present study is based on a sociocultural framework and postulates that students-here working in groups to create videos of their stories on math-related topics - participate in social activities that lead to learning. Roy Pea and his Stanford University research groups have stressed the importance of media-sharing environments in which user-generated content constitutes the core of learner engagement (Lewis, Pea, \& Rosen, 2010; Pea \& Lindgren, 2008); that is, students learn from collaboration.

For the present study, three twenty-first-century competencies have been selected from the sociocultural paradigm: (1) learner-driven knowledge creation, (2) collaboration, and (3) digital media competencies that are connected to video products as cultural artifacts.

\section{Learner-driven Knowledge Creation and Math Literacy}

In DST, students are knowledge creators. They need to inquire, analyze, and apply knowledge to their stories. In the current study, the students learned new content about geometry independently while in collaborative groups and without the instruction of teachers. In designing their scripts and producing videos, they had to find and sift through the information they needed for their stories, which they would use to teach math to other peer groups. This entailed making many decisions and dealing with unpredictable situations, which often involved problems when combining videos.

In the current study, the aim was for students to learn math concepts and math literacy (ML), which has emerged as an important concept in math education (e.g., Machaba, 2018; Masal \& Yilmazer, 2014; Uzunboylu, Arslan, \& Yavuz, 2012; Vithal \& Bishop, 2006). ML offers new ways of enhancing students' motivation to learn math, making it more meaningful in real-life contexts and better able to tackle emotional issues, such as math anxiety. In the framework of the Program for International Student Assessment (PISA), ML is understood as follows (OECD, 2006): Learners identify and understand the role of math in today's world.

In the present study, students applied math concepts to practice in such a way that their audience-here being other peer groups-could understand the knowledge related to the task 
and how to use this knowledge. Machaba (2018) asserted that ML aims to develop the capability and willingness to use math concepts to make sense of many life situations. ML contains a few unique features. First, it is based on content but is connected to authentic real-life contexts; learners have to solve both the familiar and unfamiliar problems and tasks required for decision making and communication. Second, ML integrates subject matter content and/or skills in solving problems. These features are also needed in the new pedagogy of math teaching. The key aim of $M L$ is that students understand how math relates to everyday life and that they find learning meaningful and emotionally inspiring. If students do not fear math and embrace it, they can succeed (Uzunboylu et al., 2012; Whyte \& Anthony, 2012). Jablonka (2003) contended it is not possible to promote a conception of ML without simultaneously-implicitly or explicitlypromoting a particular social practice. This means that students should have the chance to discuss and communicate about math concepts with one another. Twenty-first-century competencies and ML have many overlapping features. In the present case, the students had to think about how to create the video with math knowledge so that the audience could understand the main concepts and message.

Mevarech and Kramarski (2014) stressed that twenty-first-century competencies and math learning should be integrated, and they noted that mathematical communication is an important route for acquiring relevant skills. They proposed that students in all age groups should be encouraged to engage in mathematical discourses and share ideas and solutions, as well as explain their own thinking. Developing these competencies may result in enhancing social skills and producing mathematically literate citizens.

\section{Collaboration}

Students' work in the DST project was based on collaboration, which is the main aspect of learning in sociocultural theories. Collaboration is a social mediator that allows or requires students to share their ideas (Hull et al., 2009; Pea \& Lindgren, 2008; Rogoff, 1990; Wells, 1999); it ensures that in the future, students can learn and work in the global world. Students need to develop the following competencies that go beyond the purely cognitive: social skills, cultural literacy and understanding, and help-seeking and help-giving strategies. Learning is a continuous process of dialogical interaction with other people and cultural artifacts. In distributed cognitions and interactions with different artifacts, people bring remarkable value that enhances their learning and competencies. These processes are mutually constitutive, and all learners are also contributors.

\section{Digital Competencies and Literacy}

In the current DST project, students used video technology as a tool. Digital competencies and literacy are listed in many future learning articles but also with remarks that technological environments are needed for learning these competences (e.g., Binkley et al., 2012; Griffin et al., 2013; OECD, 2010, 2013). Digital learning environments enable learners to gain numerous cognitive competencies and capacities, and digital literacy helps students develop critical skills for engaging with, consuming, and producing digital media. Facilitating students to work with digital tools in technology-rich environments prepares them to live in a world of digital transformation, one that is continuously changing how people work, communicate, play, and 
experience their daily lives. In the DST setting, students are both the users and consumers of digital media.

\section{Engagement}

The concept of 'engagement' has become important in recent learning and motivation research. Engagement levels are very strong predictors of math learning outcomes (Ayotola \& Adedeji, 2009). Taylor and Parsons (2011) analyzed the concept of engagement and found several types: academic, cognitive, intellectual, institutional, emotional, behavioral, social, and psychological. A common feature of all these definitions is that learners are motivated and actively involved in learning processes and that they experience learning to be relevant, real, and intentionally interdisciplinary. It often means moving learning from the classroom into the community, hence creating a learning climate that encourages risk-taking and prepares learners to have high expectations. Engagement often includes collaboration in the form of "peer-to-peer" relationships between students and teachers. Technology-rich learning environments can also enhance engagement.

Persistence is a part of engagement and a key concept in Bandura's (1986) self-efficacy conceptualization. Self-efficacy beliefs influence student effort, persistence, and the cognitive resources that students bring to their tasks. Persistence is one important indicator of engagement, but positive emotions during the collaborative process are also important, acting as a kind of fuel propelling learners toward a goal. Reeve, Jang, Carrell, Jeon, and Barch (2004) contended that engagement refers to a person's behavioral intensity and emotional quality during a task; in other words, engagement makes learning enjoyable.

Suwardy, Pan, and Seow (2013) investigated digital storytelling and engagement, and they found that digital storytelling is a powerful tool for the twenty-first-century classroom, providing an effective platform for making abstract content more accessible and facilitating discussions about topics in the story. The process encourages student participation and engagement, helping them better learn the concepts. Suwardy et al. (2013) emphasized that digital stories, especially student-led productions, demand a certain level of understanding about the topic, which prompts the students to reflect and think more deeply as they personalize their experiences and communicate their ideas (cf. Sandars, Murray, \& Pellow, 2008). Overall, successful storytelling goes beyond engaging students: it inspires less enthusiastic and motivated students and also creates a stronger sense of purpose in learning (Hull \& Katz, 2006).

In the current DST project, which is based on earlier studies (e.g. Niemi \& Multisilta, 2015; Niemi et al. 2014 ), the hypothesis was that the DST method could increase positive emotional experiences-including fun, aspiration and inspiration, enthusiasm, and commitment-and could also increase the students' ability to be persistent. The hypothetical basis for the design of the current study was that DST would have a positive impact on ML and engagement in math learning. The main concepts of the study are presented in Figure 1.

\section{Research Questions}

The following research questions focus on the students' and teachers' experiences with DST in learning: 
- How do students learn and work with DST?

- How do twenty-first-century competencies and ML influence students' engagement?

- What are teachers' perceptions of using DST in math learning?

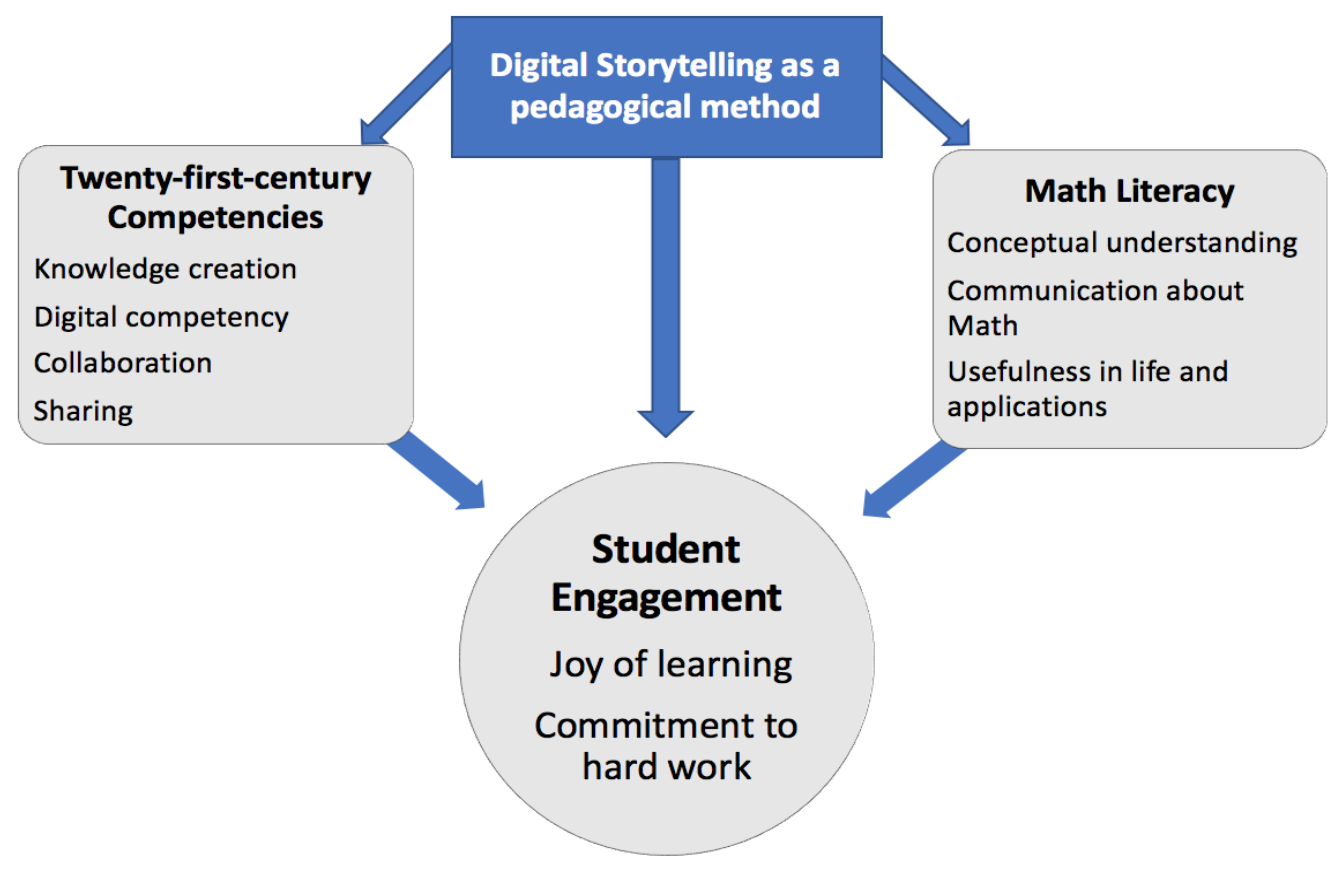

Figure 1. The Main Theoretical Concepts of the Study

\section{Methodology}

\section{Participants}

The project took place from November to December 2016 among 10-11-year-old pupils at a Finnish primary school and a Chinese primary school (Table 1).

Table 1. Study Participants

\begin{tabular}{|c|c|c|c|c|c|c|}
\hline Students & Girls & Boys & Total & $\begin{array}{l}\text { Number of } \\
\text { classes }\end{array}$ & $\begin{array}{c}\text { Number of } \\
\text { DST } \\
\text { lessons }\end{array}$ & Age \\
\hline Finnish school & $21 / 15^{*}$ & $26 / 22$ & $47 / 37$ & 2 & $7-8$ & $\begin{array}{l}10-11 \\
\text { years }\end{array}$ \\
\hline $\begin{array}{l}\text { Chinese } \\
\text { school }\end{array}$ & 60 & 70 & $130 / 108$ & 4 & $6-10$ & $\begin{array}{l}10-11 \\
\text { years }\end{array}$ \\
\hline
\end{tabular}

*Pre- and postmeasures: Some students were absent because of illness or other reasons during postmeasurements. 
For each country, the students did not form a random sample. The classes were selected based on the teachers' interest in applying DST in their school settings. The students were from local areas and were not selected using any special criteria. The aim was not to compare Finnish and Chinese classrooms in terms of learning outcomes; rather, it was to learn how DST as a studentdriven method can be applied in different educational contexts. Each class had its own schedule, and the project was integrated into math lessons during normal school days. The common theme was geometry, specifically how to measure and calculate surface area and apply this knowledge to the students' everyday lives. The students worked in small groups and created videos to share their ideas with their peers.

\section{Research Context}

Even though the Finnish and Chinese educational systems have different curricula, with the Chinese system being very centralized and the Finnish system being decentralized, the current study's intervention had a common goal in both countries: to support students' active knowledge creation and collaborative learning. In the DST project, the teachers did not teach the content; instead, they brought up the theme to students and helped the students access help.

In China, the participating teachers were math teachers, and a researcher kept in close contact with them and communicated through WeChat; this was important since these teachers did not have earlier experience with student-driven methods and were using DST for the first time. In Finland, the school was a university teacher training school, and the teachers had a good amount of experience with student-centered work, though not with DST. In Finland, the student teachers took an active role in the DST project but could were not present until the end of the project. This may have impacted the students' experiences.

In the Chinese classes, the objectives focused more on declaring concepts in geometry, whereas in the Finnish classes, the students focused more on the applications of geometrical knowledge. The role of the research team was to support teachers in the pedagogical design and overall project implementation by offering training and insights based on previous research. However, the researchers did not intervene in any practical or pedagogical arrangements in the classrooms. The themes of the videos are presented in Table 2.

Table 2. Video Themes in Finnish and Chinese Classes

\begin{tabular}{ll}
\hline Videos & Finnish students \\
\hline Story 1 & A candy box, of a suitable size for children and capable of being recycled. \\
\hline Story 2 & A big box for surprise gift toys. \\
\hline Story 3 & A shoe box, in which you can see what kind of shoes are in the box. \\
\hline Story 4 & A box for a suitably sized watch/clock. \\
\hline Story 5 & A spacious laptop box made from recycled materials. \\
\hline Story 6 & A box for an iPhone that can be turned into a protective cover for the iPhone. \\
\hline & Chinese students \\
\hline Five stories & Calculate the area of a parallelogram. \\
\hline Sixht stories & Calculate the area of a trapezoid. \\
\hline
\end{tabular}


In the current study, the DST process was implemented in the following phases:

Phase 1: The students worked in small groups (four to six students in a group) on the geometry task given by the teacher, explored the task, and researched the subject by using their textbooks, the Internet, libraries, and also sources at home. Throughout the process, the teachers were facilitators.

Phase 2: The student groups designed their DST (e.g., prepared a scenario or made a storyboard and allocated roles).

Phase 3: The student groups used tablets and/or smartphones to shoot their digital stories. Each group had at least one tablet; some groups had more. The group was responsible for the joint video product.

Phase 4: The student groups edited their story (e.g., cut or mixed scenes, added subtitles, background music, tags and story metadata) and uploaded it to a common server.

Phase 5: The groups presented the digital stories to their peer groups.

Phase 6: The students offered feedback on their peers' work. To ensure the evaluation was constructive, student feedback was based on guiding questions (or rubrics), for example, about the content, design and originality of the presentation.

\section{Data Gathering}

The study design included both quantitative and qualitative research methods. At the beginning of the project, the students completed a questionnaire asking about their background information. After every lesson, the students assessed their DST experiences by completing a structured questionnaire with seven items. Because the questionnaires were for 10-11-yearolds, they had to be short and easy to complete. After the project, the students assessed how DST influenced their learning. To obtain further insights into the process, the researchers visited the schools, observed the students' work and their videos, and, after the project, interviewed the teachers, student teachers, and one Chinese principal. One researcher observed the Chinese classrooms, and one observed the Finnish classrooms; each researcher visited about one-third of the sessions.

\section{The Instruments}

The process of designing and validating the instruments in three languages had many phases. All the instruments were designed collaboratively by an English-speaking researcher, a Chinesespeaking researcher, and a Finnish-speaking researcher. The meanings of each question and set of instructions were checked several times, ensuring that they could be understood in the same way. Also, the questions were first tested among a few students in Finland and China to make sure that these students could understand the meaning and how they were expected to respond. The questionnaires and their relationship to the utilized theoretical concepts are presented in Table 3. 
Table 3. Theoretical Concepts and Questionnaires

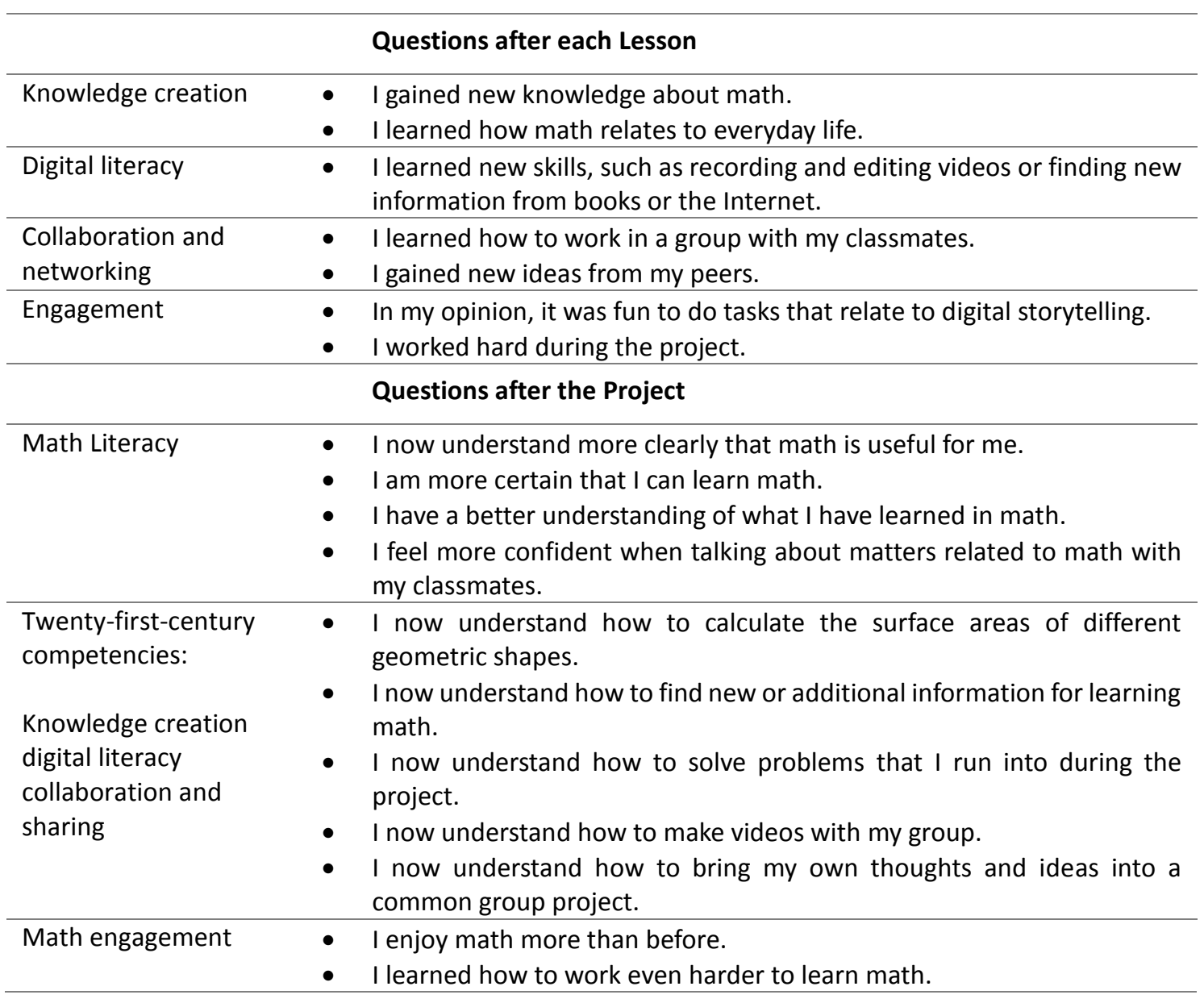

The observations in the classrooms were based on the main concepts of the study, particularly on students' active involvement in the work and their collaboration. The interview questions focused on how the teachers estimated DST as a pedagogical method.

\section{Data Analysis}

The quantitative data were analyzed using descriptive statistics, such as mean values and standard deviations. Because the students were not the random sample, the differences between countries were not tested statistically. The relationships between the main concepts were investigated first by correlations, and then, for further analysis, a linear regression analysis was used. It was applied to investigate how math literacy (ML) and twenty-first-century competencies (21C) influenced on engagement (enjoyment and on hard work).

The summative variables of the items for ML (four items, $\alpha$ values: .96 in the Chinese and .97 in the Finnish data) and 21C (five items, $\alpha$ values: .92 in the Chinese and .91 in the Finnish data) were calculated. There were high correlations between the summative variables of the main concepts: $21 \mathrm{C}, \mathrm{ML}$, and engagement. 
The analysis was constructed on the assumption that the students' motivation would be a basic force for their future learning; and here, it is important to see how motivation can be enhanced through pedagogical methods. Therefore, engagement was set as a dependent variable. The model could have been constructed in an alternative way by setting engagement as an explanatory variable, but the design of the study and contents of the questionnaires led to the model that was used. In the present study, the aim was to see what impacts engagement. Finally, the qualitative data were analyzed using a content analysis.

\section{Findings}

\section{Students' Experiences}

The first research question focuses on how students learn and work with DST. The students completed the daily questionnaire after each DST session (in Finland, three to six times; in China six to 10 times, depending on the class). There were slight variations between the sessions, but in general, the students rated their experiences with very high scores (see Figure 2). To discern the trend during the sessions, the mean values for the first and final sessions and for two sessions (every second or third, depending on the class) in between were calculated. The results are shown in Figure 2. The histograms show that there are high values throughout the project. Collaboration and engagement are high from the beginning and continue at elevated levels until the end. Engagement is extremely high for both countries. In general, the students worked hard, showing much enjoyment and high levels of collaboration throughout the project.

The means of the classes varied, mainly between nine and 10 for the Chinese classes. In the Finnish classes, the values were moderate, varying between seven and eight. One Finnish class had IT difficulties in the beginning, specifically in recording and editing videos ( $M=6.34$ ), but they still managed to produce a complete video. It seems that technical video editing was also a challenge in two Chinese classes; they had technical problems in the end phase when it came to uploading the videos. 

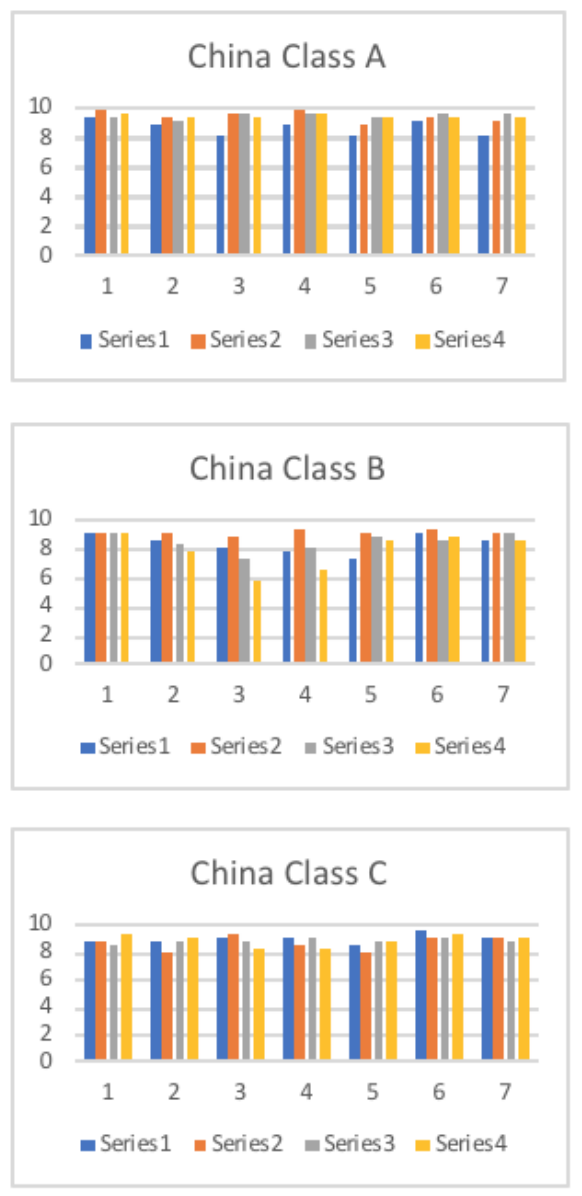
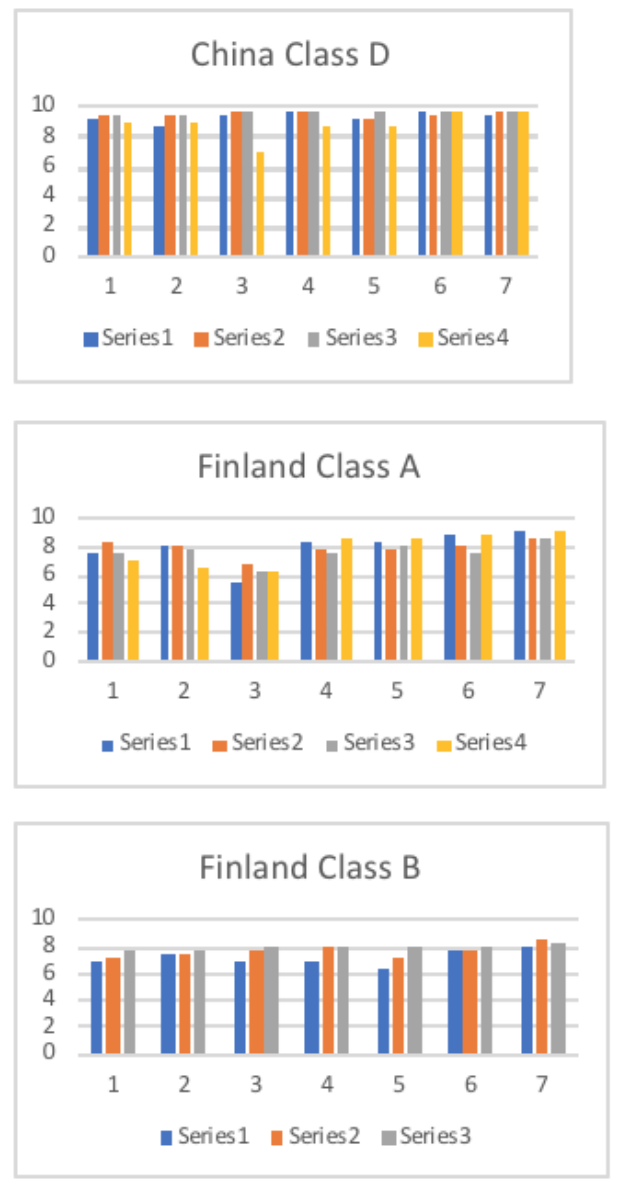

Figure 2. The Students' Experiences during the DSTproject ("I learned the following things during the storytelling project").

Series 1: Beginning of the project. Series 2-3: Two checking points during the project. Series 4: At the end of the project. Finnish Class B had only three measurements.

1. I learned new knowledge about math.

2. I learned how math relates to everyday life.

3. I learned new skills such as recording and editing videos and finding new information from books or the Internet.

4. I learned how to work in a group with my classmates.

5. I gained new ideas from my peers.

6. In my opinion, it was fun to do tasks that relate to digital storytelling.

After the project, the students responded to the questionnaire that asked them to evaluate what impact the DST had on their competencies (Table 4). The Chinese students' mean values of learning experiences varied between $8.93(S D=2.7)$ and $9.62(S D=1.28)$. The Finnish values were systematically lower, the means ranging from $M=6.60$ to $M=7.68$ and with wider SDs (2.58-3.16). 
Table 4. Student Assessments of their Learning after the Project

\begin{tabular}{|c|c|c|c|c|}
\hline $\begin{array}{l}\text { How well do the following statements describe you } \\
\text { after the digital storytelling project? Scale 1-10 }\end{array}$ & $\begin{array}{l}\text { Finnish } \\
\text { Means }\end{array}$ & $\begin{array}{l}\text { Chinese } \\
\text { Means }\end{array}$ & $\begin{array}{l}\text { Finnish } \\
\text { SD }\end{array}$ & $\begin{array}{l}\text { Chinese } \\
\text { SD }\end{array}$ \\
\hline \multicolumn{5}{|l|}{ ML } \\
\hline I now understand more clearly that math is useful for me. & 7.42 & 9.03 & 2.75 & 1.83 \\
\hline I am more certain that I can learn math. & 7.56 & 8.95 & 2.81 & 1.89 \\
\hline $\begin{array}{l}\text { I have a better understanding of what I have learned in } \\
\text { math. }\end{array}$ & 7.58 & 8.93 & 2.71 & 1.86 \\
\hline $\begin{array}{l}\text { I feel more confident when talking about matters relating } \\
\text { to math with my classmates. }\end{array}$ & 7.35 & 8.97 & 2.96 & 1.88 \\
\hline
\end{tabular}

\section{Twenty-first-century competencies}

\begin{tabular}{|c|c|c|c|c|}
\hline $\begin{array}{l}\text { I understand how to calculate the surface areas of } \\
\text { different geometric shapes. }\end{array}$ & 7.68 & 9.62 & 2.58 & 1.28 \\
\hline $\begin{array}{l}\text { I understand how to find new or additional information for } \\
\text { learning math. }\end{array}$ & 7.35 & 9.37 & 2.76 & 1.49 \\
\hline $\begin{array}{l}\text { I understand how to, in practice, make videos with my } \\
\text { group partners. }\end{array}$ & 7.14 & 9.39 & 3.00 & 1.60 \\
\hline $\begin{array}{l}\text { I understand how to bring my own thoughts and ideas into } \\
\text { a common group project. }\end{array}$ & 7.73 & 9.34 & 2.61 & 1.55 \\
\hline $\begin{array}{l}\text { I understand how to solve problems I ran into during the } \\
\text { project. }\end{array}$ & 7.57 & 9.44 & 2.63 & 1.35 \\
\hline \multicolumn{5}{|l|}{ Engagement } \\
\hline I enjoy math more than before. & 6.60 & 8.94 & 3.16 & 1.83 \\
\hline I learned how to work even harder to learn math. & 7.72 & 9.12 & 2.82 & 1.74 \\
\hline
\end{tabular}

The findings show a general trend: The Chinese students have higher scores for all the variables, and the Finnish students show more moderate values. This may be a cultural effect or may be because the videos were slightly different in China and Finland. The Chinese students focused on math concepts, while the Finnish students focused more on applications of knowledge. In a fairly short time frame, creating applications where the concepts could be used was demanding. When the Finnish students evaluated their peers' videos, some students mentioned that "there should have been more math." The reason for these differences may also be that collaborative learner-centered working methods were new and exciting to the Chinese students, while in the Finnish schools, they were the standard.

The researchers' observations confirmed the quantitative findings. Both the Finnish and Chinese students used math-related concepts in the videos, but the Chinese students focused on introducing math concepts for learning and less on real-life applications. Conversely, the Finnish students concentrated more on the real-life applications of geometry. The observers also noticed that the Finnish students had more ideas, showed more "thinking outside the box," and were more focused on story elements, whereas the Chinese students demonstrated creativebut also more systematic and logical-ways to solve math problems. In both countries, the levels of collaboration were quite high. 
In both countries, the students confirmed that they had gained new knowledge about math and how math could be useful for them. They all rated ML highly. They were more certain that they could learn math and felt more confident about talking about math matters with their schoolmates, including how math relates to everyday life. The students also learned twentyfirst-century competencies: how to find new or additional information for learning math and how to bring one's own thoughts and ideas into a common group project. Collaboration with peers was also very important to them.

\section{How are Twenty-first-Century Competencies, ML, and Engagement Related?}

The second research question focused on students' engagement: persistence (working even harder to learn math) and positive emotional experiences (enjoying math more than before). Two separate regression analyses were conducted, the first one for predicting enjoyment, the second one for predicting persistency. The results are presented in Tables 5 and 6 .

Table 5. Linear Regression: Influence of ML and Twenty-First-Century Competencies on Enjoyment

\begin{tabular}{|c|c|c|c|c|c|}
\hline Variables & B & SE & Beta & $\mathrm{t}$ & $p$ \\
\hline \multicolumn{6}{|l|}{ China } \\
\hline Constant & .688 & .933 & & .738 & .465 \\
\hline Twenty-first-century competencies (six items) & .181 & .177 & .145 & 1.023 & .313 \\
\hline $\mathrm{ML}$ (four items) & .764 & .151 & .718 & 5.070 & .000 \\
\hline \multicolumn{6}{|l|}{ Finland } \\
\hline \multirow[t]{2}{*}{ Constant } & - & .949 & & -1.054 & .299 \\
\hline & 1.001 & & & & \\
\hline Twenty-first-century competencies (six items) & .069 & .180 & .050 & .381 & .706 \\
\hline ML (four items) & .955 & .153 & .818 & 6.227 & .000 \\
\hline
\end{tabular}

Note. Chinese students, $n=130 ; R^{2}=68 ; F(2,128)=145.523, p<.001$. Finnish students, $n=37$; $R^{2}=.73 ; F(2,34)=46.551, p<.001$. All variables are on a scale of $1-10$.

The analysis (Table 5) revealed that ML and twenty-first-century competencies explain $68 \%$ (Chinese data) and 73\% (Finnish data) of the variance in the dependent variable "enjoyment of learning." The most powerful independent variable at both schools was ML: The higher the math literacy was, the more students were shown to be enjoying math. The second regression analysis was intended to find out how ML and twenty-first-century competencies predicted persistency to work hard (Table 6). 
Table 6. Linear Regression: Influence of ML and Twenty-first-Century Competencies on Persistency to Work Hard

\begin{tabular}{lccccc}
\hline Variables & B & SE & Beta & t & $\mathrm{p}$ \\
\hline China & & & & & \\
\hline Constant & .813 & .627 & & 1.296 & .197 \\
\hline Twenty-first-century competencies (six items) & .138 & .081 & .098 & 1.705 & .091 \\
\hline ML (four items) & .781 & .057 & .790 & 13.736 & .000 \\
\hline Finland & & & & & \\
\hline Constant & .688 & .933 & & .738 & .465 \\
\hline Twenty-first-century competencies (six items) & .181 & .177 & .145 & 1.023 & .313 \\
\hline ML (four items) Finland & .764 & .151 & .718 & 5.070 & .000 \\
\hline
\end{tabular}

Note. Chinese students, $n=130 ; R^{2}=.73 ; F(2,128)=141.012, p<.001$. Finnish students, $n=36$; $R^{2}=.69 ; F(2,34)=37.755, p<.001$. All variables are on a scale of $1-10$.

The analysis revealed (Table 6) that ML and twenty-first-century competencies explained $69 \%$ (Chinese data) and $73 \%$ (Finnish data) of the persistency variance. In addition, regarding the two independent variables, ML was stronger than twenty-first-century competencies.

The explanatory power of the variance in the regression analyses was extremely high, varying between $68 \%$ and $73 \%$ for both countries. If the students could learn math in such a way that they could understand its value in their lives and if they could communicate math-related issues with confidence, it added to their engagement. In the Finnish data, ML has a slightly stronger effect $(\beta=.818)$ on joy in learning than on hard work $(\beta=.718)$, but in the Chinese data, the effect is reversed ( $\beta=.790, \beta=718$, respectively). However, when interpreting these results, it is important to keep in mind that the regression analysis is based on correlations and that there can always be mutual interactions between the variables; therefore, we have to be cautious when it comes to causal explanations.

\section{Teachers' Views on the Value of DST}

The third research question focused on teachers' perceptions of the value of DST. The interviews with the teachers confirmed the quantitative assessments of the students' responses and the researchers' observations. Most of the teachers' comments focused on knowledge creation, collaboration, and engagement.

All the teachers and student teachers in the Finnish schools emphasized the value of the students' own knowledge creation. A Finnish teacher noted the following:

If they can tell the story of the content they have learned, then I can believe that they really have learned the facts and the content. Because when they form the subject that they have learned into narrative form, then they use their knowledge, and then they...l think that this shows they have understood that thing. (FT1) 
The Chinese teacher agreed with this, using almost the same words, as follows:

I believe that if a student can tell something, then they have learned it very well. By writing a story, telling a story, playing, or making a drama of the contents they have learned, I believe that they have really learned. This shows that the students are able to use the knowledge. (CHT1)

The Chinese teachers noted that the students were seeking information from different sources, for example, the Internet, books, parents, teachers, and friends. The teachers in both countries stated that the students tried different methods to find the best solutions.

All the teachers stressed the value of collaboration in DST. However, one Finnish teacher also detected some tensions in collaboration:

We notice that in one small group, one person is very active, and the other two students are not so active. It is difficult for one active student to make the other two passive students join in the group work. (FST)

Another teacher described challenges to form a well-functioning group in the following way:

There is one tiny problem because we did not realize that earlier with this boy in the same group... and they had some difficulties with each other. And... it was a mistake to put them in the same group because they did not get along very well. (FT2)

Sharing culture was important for enhancing learning. It gave an opportunity to give feedback to peer groups. One Finnish student teacher described the students' critical comments:

In addition, the students offered their feedback on the need to better edit the stories. The students of Group 5, for example, although they liked Group 2's story, mentioned that "...it could have been edited into different scenes". (Group 4)

Additionally, a student teacher (A) argued the following:

In the evaluation session, where the groups offered feedback to peers' digital stories, some students felt that they should have included more mathematical terms and concepts in the stories.

When teachers described the students' engagement, they emphasized not only an active process, but also collaborative work. One Chinese teacher noted, "I think that one child is the best teacher to another child because they speak the same language."

Children were very excited and engaged during the project. One Chinese teacher noted, "Every child was very active and with high spirits." Another Chinese teacher stated the following:

When we had the digital storytelling course, during the breaks, the students would come to the teacher's office to ask something about it and ask if they can start the course earlier. This has never occurred before for other courses in the past. (CHT2)

The teachers also said that when the students presented their videos to other groups, they were very proud of what they had made. However, there were some contradictions between engagement and content learning. A Finnish teacher stated the following: "And because they were so interested in and excited about that, they kind of forgot they had mathematical content." The teacher, however, praised the method: "When they do things with the hands and 
then add the knowledge they have got and change it in the form of digital stories, I'm sure they really use the knowledge that they have got."

The interviews also revealed how teachers' roles are changing. Class teacher $\mathrm{S}$ in Finland said that DST needs hard work from all the involved parties-her, the students, and student teachers. The teachers also said the process was very creative and that the students learned in various ways, but also that the process can be unpredictable, as noted by one Finnish teacher in the following:

It is a very creative process with many elements combined together. It is a very good method. However, this also means that sometimes, we may not know or foresee what will happen next and how it goes in a later stage because students are so creative and have different ways to do things. (FT2)

A Finnish teacher noted, "This teaching method combines many elements: search for information, put the story in a structured way, different way to present the contents, very creative, group work, so many elements" (FT2).

The following perception from one Chinese teacher summarized the other teachers' opinions: "The students are very active. There are so many good elements combined together in this method. Students are doing things together. In addition, students have good motivation because we combine math learning with other contexts" (CHT3).

Teachers' feedback about DST was very positive in terms of students' knowledge creation, engagement and collaboration. However, they also recognized that their role had changed. It was more like a facilitator whose responsibility was to support students' work and help them in different critical points of working processes (see also Lee \& Tan, 2018).

\section{Discussion and conclusions}

The aim of the current study was to find out how DST in two different contexts can support students' twenty-first-century competencies, especially active knowledge creation connected with $\mathrm{ML}$, collaboration, and increased engagement in learning. With both quantitative and qualitative evidence, the current study confirms earlier research findings (e.g., Starcic, Solomonides, \& Volk, 2016, Yang, \& Wu, 2012; Niemi et al., 2014; Lambert, J. 2013, Niemi \& Multisilta, 2015; Hung et al., 2012; Robin, 2008, Kearney, 2009) that DST facilitates students' progress toward active knowledge construction, collaboration, and sharing. The results convincingly support the view of innovative learning environments (Domingo \& Gargante, 2016; OECD, 2010, 2013; Saavedra \& Opfer, 2012) in which educational technology is seen a remarkable enhancer for learning twenty-first-century competencies. Schleicher (2015) argued that educational success is no longer measured by students' ability to reproduce content knowledge but rather by their capacity to extrapolate what they know and apply that knowledge to novel situations. This study confirmed findings of earlier studies that DST creates innovative learning environments and supports learning s for future needs (e.g., Domingo, \& Gargante, 2016; Dumont et al., 2010; Robin, 2008; Sadik, 2008). The present DST study provided a pedagogical means for using digital technology to motivate students to become active learners.

In the present study, ML is shown to be an important predictor of the students' level of engagement. As evidenced by persistence and positive emotions, the students were more 
engaged if they could see the relevance of math and felt they were better able to discuss mathrelated topics with their peers. Motivation to learn math is a global concern, and ML has been the subject of much attention in the past decade (Machaba, 2018; Masal \& Yılmazer, 2014; Uzunboylu et al., 2012; Vithal \& Bishop, 2006), particularly in how to engage students and integrate ML into math lessons (Machaba, 2018; Vithal \& Bishop, 2006). In the present study, the major finding is that ML significantly affected students' engagement, and the students also confirmed that they learned math content and, in particular, how math relates to everyday life. The teachers also said that making videos for others helped the students better understand what they were learning. The current study also reinforces earlier findings that ML needs to utilize methods that are socially constructed, such as collaboration, joint knowledge construction, sharing, and communication (Lambert, 2013; Pea \& Lindgren, 2008). The present study's findings show that DST provides an active learning environment and multimodal tools for making math learning meaningful and enjoyable.

In the current study, the students had to find and create knowledge by themselves, with the teachers acting only as facilitators. The students worked in groups and had to make many choices when designing their videos. In this context, Säljö (2010) asserted that ICT transforms one's concepts of what learning entails, and today, learning is seen as an increasingly active process occurring through interactions among learners and artifacts. The current study confirmed these sociocultural assumptions, finding that students, collaborative video stories, and knowledge all interacted to support learning (see e.g., Pea \& Lindgren, 2008; Pea, 2004). An interesting feature emerging from the teachers' interviews is that the teachers not only thought that the students learned essential content, but also that DST opened up the opportunity for a more focused study of geometry because the students needed to more carefully weigh what elements would best serve the purpose of the story and how this would affect sharing it with peers. In this sense, peer collaboration was an opportunity for the students to fill in their knowledge gaps, building on one another's strengths to respond to and find solutions to different types of questions and problems.

The current study was conducted in two different educational and cultural contexts, and here, the findings revealed that DST worked well in the Chinese centralized system because the topics were connected. DST also worked in the Finnish decentralized system, which allowed for more space for different kinds of stories. In both contexts, the common elements were that the students needed to create content based on various kinds of information sources and digital tools, that all the work was done collaboratively, and that the students could complete their work successfully.

The Chinese students' assessments were systematically higher than the Finnish students' assessments. This may have been because of a cultural effect, but it also raises the question of whether the students needed more support, guidance, and time in student-driven knowledge creation. The Finnish students had fewer hours to work on their projects than the Chinese students, and they were coping with a demanding task in applying geometry concepts to reallife contexts. The Chinese students prepared more traditional math-content-based videos and had more lessons-and hence time to work on their projects. In both countries, some difficulties emerged in technical issues that showed how important it is that facilities are working well. However, these challenging situations were also problem-solving moments, and the students working with their peers and teachers could find solutions to these problems. The findings showed that working in technological environments requires continuous learning of how to use digital tools. 
In conclusion, based on the findings, the following reflections as recommendations for teaching and learning can be given: Even when the cultural and curriculum contexts vary, DST can facilitate students' learning toward obtaining twenty-first-century competencies. DST integrates digital technology with subject math learning and fosters student persistence and enjoyment in learning. The DST method requires active knowledge creation; forces students to seek out how to apply knowledge to new situations; and allows collaboration, which is one of the most important competencies in society now and in the future.

\section{Limitations and Future Research}

In the future, gaining more experience with DST and understanding how it works with different math topics and with other grade levels would better uncover how DST functions for students, along with how effective this technique can be. The time frame in the current study was fairly short in terms of producing long-term effects on students' engagement, ML, or twenty-firstcentury competencies. Hence, it would be useful to conduct longitudinal studies to more fully understand what happens regarding students' cognitive and emotional structures when they are designing, editing, and sharing their videos over an extended period of time. New methods of learning analytics could provide important information in this regard. Future research should also use other kinds of learning outcome measurements in addition to self-evaluations. Students' pre- and post-tests could provide more knowledge about the changes in their development.

\section{References}

Ayotola, A. \& Adedeji, T. (2009). The relationship between mathematics self-efficacy and achievement in mathematics. Procedia - Social and Behavioral Sciences, 1(1), 953-957. doi:10.1016/j.sbspro.2009.01.169

Bandura, A. (1986). The explanatory and predictive scope of self-efficacy theory. Journal of Social and Clinical Psychology, 4(3), 359-373. doi:10.1521/jscp.1986.4.3.359

Binkley, M., Erstad, O., Herman, J., Raizen, S., Ripley, M., Miller-Ricci, M., \& Rumble, M. (2012). Defining twenty-first century skills. In P. Griffin, B. McGaw, \& E. Care (Eds.), Assessment and teaching of 21st century skills (pp. 17-66). Dordrecht: Springer.

Blas, N. \& Paolini, P. (2013). Beyond the school's boundaries: PoliCultura, a large-scale digital storytelling initiative. Journal of Educational Technology \& Society, 16(1), 15-27.

CNNIC, (2017). China Internet Network Information Center (CNNIC). Statistical report on internet development in China (January 2017). Retrieved on 08 October 2018 from https://cnnic.com.cn/IDR/ReportDownloads/201706/P020170608523740585924.pdf.

Cole, M. \& Cigagas, X. E. (2010). Culture and cognition. In M. H. Bornstein (Ed.), Handbook of cultural developmental science (pp. 127-142). New York: Psychology Press.

Derry, S. J., Pea, R. D., Barron, B., Engle, R. A., Erickson, F., Goldman, R., . . Sherin, B. L. (2010). Conducting video research in the learning sciences: Guidance on selection, analysis, technology, and ethics. Journal of the Learning Sciences, 19(1), 3-53.

doi:10.1080/10508400903452884 
Domingo, M. G. \& Gargante. A. B. (2016). Exploring the use of educational technology in primary education: Teachers' perception of mobile technology learning impacts and applications' use in the classroom. Computers in Human Behavior, 56, 21-28.

Dumont, H., Istance. D., \& Benavides, F. (2010). The nature of learning: Using research to inspire practice, educational research and innovation. Paris: OECD.

Griffin, P., McGaw, B., \& Care, E. (2013). Assessment and teaching of 21st century skills. Dordrecht: Springer.

Hakkarainen, K., Paavola, S., Kangas, K., \& Seitamaa-Hakkarainen, P. (2013). Sociocultural perspectives on collaborative learning: Towards collaborative knowledge creation. In C. E. Hmelo-Silver, A. M. O'Donnell, C. Chan, \& C. A. Chinn (Eds.), International handbook of collaborative learning (pp. 57-73). New York: Routledge.

Hull, G. \& Katz, M.L. (2006). Crafting an agentive self: Case studies of digital storytelling. Research in the Teaching of English, 41(1), 43-81.

Hull, G., Zacher, J., \& Hibbert, L. (2009). Youth, risk, and equity in a global world. Review of Research in Education, 33(1), 117-159. doi:10.3102/0091732X08327746

Hung, C.-M., Hwang, G.-J., \& Huang, I. (2012). A project-based digital storytelling approach for improving students' learning motivation, problem-solving competence and learning achievement. Educational Technology \& Society, 15(4), 368-379.

Jablonka, E. (2003). Mathematical literacy. In A. J. Bishop, M. A. Clements M. A., C. Keitel, J. Kilpatrick, F., \& K. S. Leung (Eds.), Second international handbook of mathematics education (pp. 75-102). Dordrecht: Springer.

Jenkins, H., Purushotma, R., Weigel, M., Clinton, K., \& Robison, A. J. (2009). Confronting the challenges of participatory culture: Media education for the 21st century. Chicago, IL: MacArthur Foundation and London: MIT Press.

Kearney, M. (2009, December). Towards a learning design for student-generated digital storytelling. Paper presented at the The Future of Learning Design Conference. University of Wollongong, New South Wales, Australia. Retrieved on 08 October 2018 from http://ro.uow.edu.au/gi/viewcontent.cgi?article=1003\&context=fld

Lambert, J. (2013). Digital storytelling: Capturing lives, creating community. New York: Routledge.

Lee, W. O. \& P-L. Tan. (2018). The new roles for twenty-first-century teachers: Facilitator, knowledge broker, and pedagogical weaver. In H. Niemi, A. Toom, A. Kallioniemi, and J. Lavonen (Eds.), The teacher's role in the changing globalizing world: Resources and challenges related to the professional work of teaching (pp.11-31). Leiden: Brill Sense.

Lewis, S., Pea, R., \& Rosen, J. (2010). Beyond participation to co-creation of meaning: Mobile social media in generative learning communities. Social Science Information, 49(3), 351369. doi:10.1177/0539018410370726

Machaba, F. M. (2018). Pedagogical demands in mathematics and mathematical literacy: A case of mathematics and mathematical literacy teachers and facilitators. Eurasia Journal of Mathematics, Science and Technology Education, 14(1), 95-108. doi:10.12973/ejmste/ 78243 
Masal, M. \& Yılmazer, G. (2014). The relationship between secondary school students' arithmetic performance and their mathematical literacy. Procedia - Social and Behavioral Sciences, 152, 619-623. doi:10.1016/j.sbspro.2014.09.253

McGee, P. (2015). The instructional value of digital storytelling: Higher education, professional, and adult learning settings. New York: Routledge.

Multisilta, J. A. \& Niemi, H. M. (2017). Tools, pedagogical models, and best practices for digital storytelling. In M. Khosrow-Pour (Ed.), Encyclopedia of information science and technology (4th ed.). Hershey, PA: IGI Global.

Niemi, H. \& Jia, J. (2016). What are new ways to teach and learn in China and Finland? In H. Niemi \& J. Jia (Eds.) New ways to teach and learn in China and Finland. Crossing Boundaries with Technology (pp.9 -18). New York: Peter Lang.

Niemi, H., Harju, V., Vivitsou, M., Viitanen, K, Multisilta, J., Kuokkanen, A. (2014). Digital storytelling for 21st-century skills in virtual learning environments, Creative Education, 5(9), 657-671.

Niemi, H., Kynäslahti, H., \& Vahtivuori-Hänninen, S. (2013). Towards ICT in everyday life in Finnish schools: Seeking conditions for good practices. Learning, Media \& Technology, 38(1), 57-71. DOI10.1080/17439884.2011.651473

Niemi, H. \& Multisilta, J. (2015). Digital storytelling promoting twenty-first century skills and student engagement. Technology, Pedagogy and Education. doi: http://dx.doi.org/ 10.1080/1475939X.2015.1074610

OECD. (2006). Assessing scientific, reading and mathematical literacy: A framework for PISA. Paris: OECD.

OECD. (2010). Inspired by technology, driven by pedagogy: A systemic approach to technologybased school innovations, educational research and innovation. Paris: OECD. http://dx.doi.org/10.1787/9789264094437-en.

OECD. (2013). Innovative learning environments, educational research and innovation. Paris: OECD.

Pea, R. \& Lindgren, R. (2008). Video collaboratories for research and education: An analysis of collaboration design patterns. IEEE Transactions on Learning Technologies, 1(4), 235247. doi:10.1109/TLT.2009.5

Pea, R. D. (2004). The social and technological dimensions of scaffolding and related theoretical concepts for learning, education, and human activity. Journal of the Learning Sciences, 13(3), 423-451. doi:10.1207/s15327809jls1303_6

Penttilä, J., Kallunki, V., Niemi, H. M., \& Multisilta, J. (2016). A structured inquiry into a digital story: Students report the making of a superball. International Journal of Mobile and Blended Learning, 8(3), 19-34. doi:10.4018/ijmbl.2016070102

Reeve, J., Jang, H., Carrell, D., Jeon, S., \& Barch, J. (2004). Enhancing students' engagement by increasing teachers' autonomy support. Motivation and Emotion, 28(2), 147-169. doi:10.1023/B:MOEM.0000032312.95499.6f

Robin, B. R. (2008). Digital storytelling: A powerful technology tool for the 21st century classroom. Theory Into Practice, 47(3), 220-228. doi:10.1080/00405840802153916

Rogoff, B. (1990). Apprenticeship in thinking: Cognitive development in social context. New York: Oxford University Press. 
Saavedra, A. R. \& Opfer, V. D. (2012). Learning 21st-century skills requires 21st-century teaching. Phi Delta Kappan, 94(2), 8-13. doi:10.1177/003172171209400203

Sadik, A. (2008). Digital storytelling: A meaningful technology-integrated approach for engaged student learning. Educational Technology Research and Development, 56(4), 487-506. doi:10.1007/s11423-008-9091-8

Sandars, J., Murray, C., \& Pellow, A. 2008. Twelve tips for using digital storytelling to promote reflective learning by medical students. Medical Teacher, 30: 774-777. doi:10.1080/ 01421590801987370

Schleicher, A. (2015). Foreword. In Educational research and innovation: Schooling redesigned towards innovative learning system. Paris: OECD.

Shelby-Caffey, C., Úbéda, E., \& Jenkins, B. (2014). Digital storytelling revisited. The Reading Teacher, 68(3), 191-199. doi:10.1002/trtr.1273

Starcic, M., Solomonides, I., \& Volk, M. (2016). Engaging preservice primary and preprimary school teachers in digital storytelling for the teaching and learning of mathematics. British Journal of Educational Technology, 47(1), 29-50. doi:10.1111/bjet.12253

Statistics Finland, (2016). Finnish residents use the Internet more and more often. Retrieved on 08 October 2018 from http://tilastokeskus.fi/til/sutivi/2016/sutivi_2016_2016109 _tie_001_en.html?ad=notify.

Stewart, K. D. \& Ivala, E. (2017). Silence, voice, and "other languages": Digital storytelling as a site for resistance and restoration in a South African higher education classroom. British Journal of Educational Technology, 48(5), 1164-1175. doi:10.1111/bjet.12540

Suwardy, T., Pan, G. \& Seow, P.-S. (2013). Using digital storytelling to engage student learning. Accounting Education, 22 (2), 109-124. https://doi.org/10.1080/09639284. 2012.748505

Sukovic, S. (2014). iTell: Transliteracy and digital storytelling. Australian Academic \& Research Libraries, 45(3), 205-229. doi:10.1080/00048623.2014.951114

Säljö, R. (2010). Digital tools and challenges to institutional traditions of learning: Technologies, social memory and the performative nature of learning. Journal of Computer Assisted Learning, 26(1), 53-64. doi:10.1111/j.1365-2729.2009.00341.x

Säljö, R. (2012). Schooling and spaces for learning: Cultural dynamics and student participation and agency. In E. Hjörne, G. V. d. Aalsvoort, \& G. Abreu (Eds.), Learning, social interaction and diversity - exploring school practices (pp. 9-14). Rotterdam: Sense.

Taylor, L. \& Parsons, J. (2011). Improving student engagement. Current Issues in Education, 14(1), 1-33

Uzunboylu, H., Arslan, C., \& Yavuz, G. (2012). A study on mathematical literacy self-efficacy beliefs of prospective teachers. Procedia - Social and Behavioral Sciences, 46, 5622-5625. doi:10.1016/j.sbspro.2012.06.484

Vithal, R. \& Bishop, A. J. (2006). Mathematical literacy: A new literacy or a new mathematics? Pythagoras, 64, 2-5.

Vygotsky, L. (1978). Mind in society. Cambridge, MA: MIT Press. 
Wang, S. \& Zhan, H. (2010). Enhancing teaching and learning with digital storytelling. International Journal of Information and Communication Technology Education, 6(2), 7687.

Wells, G. (1999). Dialogic inquiry: Towards a socio-cultural practice and theory of education. Cambridge, MA: Cambridge University Press.

Whyte, J. \& Anthony, G. (2012). Maths anxiety: The fear factor in the mathematics classroom. New Zealand Journal of Teachers' Work, 9(1), 6-15.

Woodhouse, J. (2008, June 23-25). Story-telling: A telling approach in healthcare education. Paper presented at the Narrative Practitioner Conference. Wrexham, UK.

Yang, Y.-T. C. \& Wu, W.-C. I. (2012). Digital storytelling for enhancing student academic achievement, critical thinking, and learning motivation: A year-long experimental study. Computers \& Education, 59(2), 339-352. doi: 10.1016/j.compedu.2011.12.012

Correspondence: Hannele Niemi, Professor and Research Director, Faculty of Educational Sciences, University of Helsinki, Helsinki, Finland 